\title{
Aleksandra Seidel-Mączyńska
}

oseidel@wp.pl

\section{Máchowskie fascynacje i inspiracje Jana Čepa}

\begin{abstract}
Seidel-Mączyńska Aleksandra, Máchowskie fascynacje i inspiracje Jana Čepa (Jan Čep's fascinations and inspirations of Karel Hynek Mácha). „Poznańskie Studia Slawistyczne” 1. Poznań 2011. Rys Press, pp. 229-243. ISSN 2084-3011.
\end{abstract}

Among various Čep's literary fascinations, Karel Hynek Mácha retains an important place. The Romantic writer (Mácha) and the 20th century Catholic novelist (Čep) are connected mainly by the same conception of a man in his relationship with the world and God. They share the same approach towards the passing of time, which in turn seems to be the key to being and understanding existence. The fascination dedicated to Mácha's writing seems to conceal the vision of poets and source of creation shared by both the authors. Art and artists take on a specific role, which results from the particular spiritual predispositions of the author and from his metaphysical anxiety, which has its roots in the perception of mystery surrounding humankind and the world.

Keywords: Jan Čep, Karel Hynek Mácha, time in literature, existentialism, conception of creation.

Pytanie o Karla Hynka Máchę w kontekście twórczości Jana Čepa (1902-1974), czeskiego katolickiego pisarza, żyjącego od 1948 roku na emigracji w Paryżu, nie jest pytaniem zupełnie bezzasadnym i nie pojawia się przypadkowo. Čep, w okresie międzywojennym jeden z najbardziej znanych prozaików utożsamianych z nurtem literatury katolickiej w Czechach, później z racji działań władzy komunistycznej na kilkadziesiąt lat częściowo zapomniany, był zawsze przez krytyków - nie tylko swojej doby - uważany przede wszystkim za wyraziciela 
metafizycznych i egzystencjalnych niepokojów zwykłego człowieka. Odzwierciedlają to również jego filozoficzne i literackie odniesienia, przy czym wśród licznych autorów, którymi Čep fascynował się jako czytelnik bądź inspirował jako twórca, a których często wymienia w swoich esejach i tekstach publicystycznych, Mácha zajmuje jedno z ważniejszych miejsc. A fascynacji owych - można dodać - było wiele, począwszy od literatury antycznej, skończywszy na dwudziestowiecznej. Odnajdziemy tu Platona, świętego Augustyna, Tomasza z Akwinu, Owidiusza, Wergiliusza i Horacego, Dantego, Szekspira i Pascala, a także współczesnych Čepowi (lub tworzących pod koniec XIX wie$\mathrm{ku}$ ) pisarzy francuskich i angielskich, takich jak: Georges Bernanos, Maurice Baring, Robert L. Stevenson, Charles Peguy, François Mauriac, Paul Claudel, Alain-Fournier czy Henri Pourrat. Te ostatnie fascynacje umacniane były zresztą wieloletnią pracą przekładową, w której autorowi pomagała też znajomość języków obcych (choć, jak sam skromnie przyznawał, żadnego nie znał dobrze, to znakomicie sprawdzał się jako tłumacz literatury ${ }^{1}$ ), recenzencko-krytyczną oraz osobistymi spotkaniami i przyjaźniami Čepa z niektórymi z wymienionych pisarzy, przy czym niemałe znaczenie miało tu na pewno poczucie głębokiej - i rozwijanej zarazem na płaszczyźnie kulturalno-literackiej - więzi z Francją, będącą, jak sam pisarz mawiał jeszcze przed emigracją, ,jego drugą ojczyzną", ojczyzną duchową.

Obok odniesień Čepa do literatury światowej niemało jest w jego tekstach także wzmianek o pisarzach i dziełach czeskich. Wśród nich, poza Karlem Hynkiem Máchą, najczęściej pojawiają się: Karel Jaromír Erben, Božena Němcová, Julius Zeyer, Otokar Březina, Jakub Deml, Vladislav Vančura. Dla historyka literatury takie bezpośrednie odnie-

1 „Byl jsem vždycky velkým čtenářem. Táto záliba se ve mně spojovala s další mou slabůstkou: s vášní filologickou, mohu-li to tak nazvat. Až do své čtyřicítky jsem studoval aspoň deset cizích jazyků. Rozumí se samo sebou, že umím německy, francouzsky a anglicky; dost zběžně jsem četl italsky, španělsky a dokonce také rusky. Ale zároveň musím říci, že mluvím všemi těmi jazyky dost špatně, dokonce i těmi, které znám nejlépe. To bezpochyby z velké části souviselo s mou prací překladatelskou: velmi dobře jsem cítil melodické hodnoty cizích jazyků, odstíny slov a výrazů a velmi dobře se mi dařilo nelézat pro ně rovnocenné výrazy ve své rodné řeči” (J. Čep, Poutník na zemi, Brno 1998, s. 217).

2 Ibidem, s. 224. 
sienia są oczywiście zawsze pretekstem do poszukiwania pokrewieństw między autorami, a w konsekwencji też wszelkich literackich ,miejsc wspólnych", dzięki którym możliwe staje się określenie zarówno linii rozwojowych (gatunków literackich, kierunków artystycznych, metod twórczych poszczególnych autorów itp.), jak i krytyczna diagnoza danego momentu w historii literatury, uwzględniająca cały jej kontekst. W przypadku Čepa wielość i złożoność odniesień, tak różnorodnych pod względem choćby gatunkowym, tematyczno-problemowym czy prezentowanej podbudowy filozoficzno-światopoglądowej, może jednak, jeśli nawet nie komplikować, to na pewno nie dawać łatwych podpowiedzi przy poszukiwaniu w nich zwartego i jednolitego kompleksu cech, które pozwalałyby tworzyć jedną konkretną linię rozwoju z pisarstwem Čepa. Proza pisarza nie poddawała się zresztą nigdy zbyt łatwo uogólniającym interpretacjom i próbom formalnego zaszeregowania do któregoś z istniejących wówczas (lub wcześniej) kierunków artystycznych (nawet jako epigońska wobec nich). Jednoznaczne określenie jego metody twórczej od samego początku napotykało trudności i właściwie zawsze kończyło się ostatecznie niepowodzeniem³ ${ }^{3}$ Pomimo że twórczość Čepa czerpie z tradycji czeskiej literatury (i to na tyle świadomie, że dzięki sugestywności i sile słowa potrafi ją niezwykle odświeżyć), to kontekst literacki, w którym umieszczano zawsze jego dzieła, okazywał się albo niepełny, albo też w całościowym interpretacyjnym rozrachunku nieodpowiedni ${ }^{4}$.

3 Chodzi przede wszystkim o wpisywanie Čepa w szeregi ruralistów, od których sam autor się odżegnywał i od których rzeczywiście dzieli go wiele (comp. J. Čep, Ruralism, w: idem, Rozptýlené paprsky, Praha 1993, s. 187-188; na temat związków Čepa z ruralizmem comp. M. C. Putna, Česká katolická literatura v kontextech 1918-1945, Praha 2010, s. 1085-1086). Ponadto niektórzy ze współczesnych pisarzowi rodzimych krytyków dopatrywali się w jego twórczości związków z tradycją katolickiej kalendarzowej literatury, określali ją całościowo jako jeden bildungsroman, a nawet dopuszczali możliwość zastosowania kontekstu psychoanalitycznego wobec niej (M. Bedřich, Dobová recepce dila Jana Čepa, w: Vira a výraz. Sborník z konference ,....bývalo u mne zotvíráno...", red. T. Kubíček, J. Wiendl, Brno 2005, s. 419). Jakkolwiek każda z tych propozycji jest po części słuszna, to żadna z nich nie zawiera takiego zestawu cech definicyjnych, którym można by objąć całą omawianą tu prozę bez uszczerbku dla jej interpretacji.

4 Czescy krytycy i badacze literatury najczęściej wskazywali na pokrewieństwo Čepa z Demlem, Březina, Máchą, Vanurą, Němcovą. Na związki pisarza z tradycją 
Oczywiście wielu z wymienionych przez samego Čepa twórców (choć nie wszystkich) można postrzegać w związku z ważną dla niego tradycją Kościoła katolickiego, jednak trudno oczekiwać, że z tego powodu ich dzieła bądź poglądy filozoficzne będą stanowić jednolity punkt odniesienia twórczości literackiej czeskiego prozaika. W najogólniejszy sposób można powiedzieć, że tym, co łączy wymienionych pisarzy i filozofów w kontekście pisarstwa Čepa, jest ich próba przyjrzenia się ludzkiej egzystencji w jej jednostkowym wymiarze i w relacji do rzeczywistości, która jest wobec niej transcendentna; jest to jednocześnie poszukiwanie koncepcji świata i człowieka często odnoszącej człowiek i jego egzystencję do jakiejś wyższej, przekraczającej granice materialności sfery (choć przecież też różnie pojmowanej u wspomianych autorów). Ponadto pamiętać trzeba, że nie każda wzmianka czy nawet recenzja krytyczna świadczy o inspiracji twórczej - może być przecież jedynie kwestią samej fascynacji czytelniczej. Jak na takim tle rysuje się zatem problem odniesień Čepa do Karla Hynka Máchy (1810-1836), przedstawiciela czeskiego romantyzmu i wielbiciela Byrona?

Nie jest to na pewno nawiązanie do Máchy jako romantyka i do romantyzmu jako kierunku ideowego czy twórczego, a więc przyjmowanie, a tym bardziej kultywowanie, romantycznego dziedzictwa. Pomimo że Čep niezwykle cenił wkład Máchy w literaturę narodową̧, fascynacja jego twórczością nie polegała u niego na kontynuowaniu konkretnej linii czy typu pisarstwa i realizowaniu danego romantycznego modelu; mieściłaby się raczej w nawiązaniu do podobnego sposobu odczuwania i odczytywania rzeczywistości. Wydaje się, że fascynacja Máchą, podobnie jak w przypadku pozostałych literackich nawiązań Čepa, przynależy do sfery rozważań dotyczących szeroko pojętej koncepcji człowieka w relacji ze światem i z innymi (także z pewnym Absolutnym i Transcendentnym Innym). Ponadto dotyczy koncepcji

czeskiego dziewiętnastowiecznego opowiadania o tematyce wiejskiej wskazywał Antonín Měšt’an (Česká literatura mezi Němci a Slovany, Praha 2002, s. 208).

„Přese všecko mrhání silami a zaškrcování národních energií může se naše moderní slovesné umění pochlubit takovými zjevy jako Mácha, Erben, Březina, zjevy, které nám může závidět každý národ, št'astnější v svém vývoji i v své povaze" (J. Čep, Rozptýlené paprsky..., op. cit., s. 310). 
pisarstwa, jaką rozwijał Čep zarówno w swojej praktyce twórczej, jak i w teoretycznych wypowiedziach w swej eseistyce.

Z najbardziej znanym dziełem Máchy, poematem Máj, Čep zetknął się, co podkreśla, we wczesnej młodości, jeszcze w latach gimnazjalnych ${ }^{6}$. Lektura ta miała na niego na tyle silny wpływ, że po latach, w dojrzałym już wieku, pisał o niej kilkakrotnie, zawsze przy tym wspominając fragment ostatniej, czwartej części poematu: ,zbortěné harfy tón, ztrhané strůny zvuk,/zašlého věku děj, umřelé hvězdy svit" ". Zawarte tu metafory przekraczania w życiu ludzkim egzystencjalnej granicy, związanej z czasowością, wydają się korespondować z wizją człowieka proponowaną przez samego Čepa, dla którego kwestia czasu i czasowości jest jedną z kluczowych spraw istnienia człowieka i zarazem najważniejszym czynnikiem kreacji świata przedstawionego w utworach. On sam o takim postrzeganiu czasowości pisze w emigracyjnym eseju Rodnýúžas:

Čas se nezastavil pro nikoho z nás, nezastavuje se nikdy, nikdy a pro nikoho se nevrací. (...) Žádné období, žádná situace lidských dějin, ba žádná situace lidského ducha se neopakuje a nemůže opakovat v stejné podobě, za stejných podmínek. Jsou chvíle, kdy si tuto skutečnost uvědomuji naléhavěji, kdy se mi najednou zjeví uplynulý čas jako nepřekročitelná plán̆, jako nebetyčná zed'; kdy jsem v pokušení pokládat jej za něco ztraceného navždy. Někteří básníci dobřre vyjádřili tuto závrat', která se dotýká samého zoufalství. Stačí si připomenout našeho Máchu.

W kontekście tych rozważań nasuwa się skojarzenie z Máchowskim Májem i fragmentem jego drugiej części, w której w przejmujący sposób powraca niczym refren motyw upływającego czasu:

Hluboké ticho. - Z mokrých stěn

kapka za kapkou splyne,

a jejich pádu dutý hlas

dalekou kobkou rozložen, jako by noční měřil čas,

J. Čep, Poutnik na zemi..., op. cit., s. 255.

7 Ibidem, s. 271, 282. Fragment poematu: K. H. Mácha, Máj, Praha 1983, s. 51.

8 J. Čep, Poutník na zemi..., op. cit., s. 11-12. 


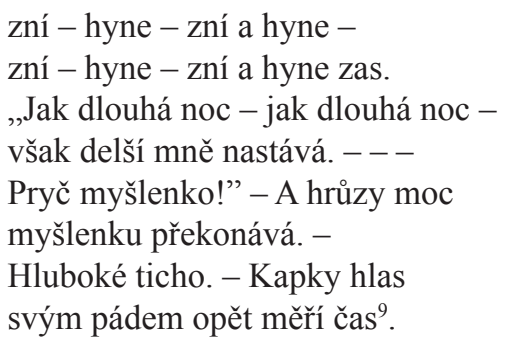

Dla Máchy zawarty w Máju problem czasowości i przemijania jest, podobnie jak u Čepa, kluczem do odczytania istoty i sposobu bycia człowieka. Bedřich Fučík pisze:

I Čep je básníkem času, snad největším u nás po Máchovi a první v próze -, odtud take jeho prudký, dramatický lyrismus. Konkretizovat čas, podat jeho krutou pomíjejícnost a žravost, je umění jedno z největších. Každý Čepův hrdina takřka hmatatelně nese na sobě strašné jizvy času; čas je jedním z neviditelných partnerů Čepových hrdinů a je takřka neustále př́tomný ${ }^{10}$.

U Máchy typowe dla romantyzmu przeświadczenie o tym, że istnienie i wszechświat pełne są niewyjaśnionych tajemnic, a teraźniejszość jest tylko przejściem między ciemnością przeszłości a ciemnością przyszłości ${ }^{11}$, przeradza się w egzystencjalną trwogę, w której pozostaje jedynie „věčná touha po absolutnu, po věčném trvání, které je člověku jako tvoru pozemskému nedosažitelné"12. Przeciwstawienie czasu i wieczności, a więc doczesnej skończoności ziemskiego bytowania i bliżej nieokreślonej absolutnej nieskończoności, rodzi u Máchy poczucie egzystencjalnego duchowego zawirowania, w którym przenika się rzeczywistość i złudzenie, życie i $\operatorname{sen}^{13}$. Nie bez znaczenia jest również fakt, że akcja poematu rozpoczyna się późnym wieczorem, w chwili, która nie jest już dniem, a jeszcze nie

\footnotetext{
$9 \quad$ K. H. Mácha, op. cit., s. 27-28.

10 B. Fučík, Svět Jana Čepa, w: idem, Píseň o zemi, Praha 1994, s. 53.

11 A. Haman, Trvání v proměně. Česká literatura devatenáctého stoleti, Praha 2007,

12 Ibidem.

13 Ibidem, s. 129.
} s. 128. 
nocą- oznacza moment ich zetknięcia, granicę czasu. Właśnie wtedy, kiedy wszystko staje się nie do końca określone, wszystko jest ,pomiędzy”, człowiek może stanąć wobec siebie samego, rozpoznać swoją sytuację egzystencjalną i siebie-w-świecie, przy czym jednocześnie pragnienie poznania i dotarcia do absolutu oraz świadomość niemożliwości spełnienia tego pragnienia rodzą głęboki metafizyczny niepokój. Z kolei przytoczona wyżej scena upływu czasu w poemacie rozgrywa się noca, która również nie spełnia tu funkcji czasu wyłącznie fizykalnego, ale ma swój wymiar duchowy, taki, który pojawia się w ludzkim doświadczeniu i związany jest ze świadomym byciem-w-świecie. Właśnie ciemność nocy przynosi świadome odkrycie głębi własnej egzystencji, może odsłaniać wyższą rzeczywistość i prowadzić do prawdy, której jasność - rozumiana w sposób platoński - ,zakryta jest przez zwykłe światło dnia i jedynie dzięki pogrążeniu sięw ciemnościach nocy możliwym staje się jej spostrzeżenie"14. Dla bohatera Máchowskiego spędzona w więziennej celi noc, która poprzedza egzekucję, to moment najgłębszego rozważania swojej egzystencji wobec całej rzeczywistości oraz czasu i wieczności.

W prozie Čepa noc ma podobne znaczenie. W napisanym już na emigracji opowiadaniu Tri pocestni to właśnie nocą otwiera się przed człowiekiem prawda o ludzkim istnieniu; dla jednego z trójki przyjaciół, którzy w środku nocy błądzą, szukając drogi do domu, ów czas bez czasu dzięki nagłemu półsennemu olśnieniu staje się chwilą wewnętrznego doświadczenia eschatologicznego, rozjaśniającego sens egzystencji. Podobny motyw nocnego błądzenia pojawia się zresztą także w dwóch wcześniejszych opowiadaniach: Zbloudilý (z tomu Vigilie, 1928) i Noční návštěva (Děravý plášt', 1934). We wszystkich trzech owo nocne zagubienie i błądzenie prowadzi ostatecznie do odkrycia metafizycznej strony rzeczywistości, całej ukrytej sfery transcendencji, a w konsekwencji prawdy o swoim byciu-w-świecie.

U Čepa przeciwstawienie czasu i wieczności ma źródło w religii katolickiej i chrześcijańskich wyobrażeniach doczesności człowieka, prowadzącej ku wiecznemu byciu z Bogiem po śmierci, dlatego - jak pisze w innym miejscu Fučík - „Čepova láska k pomíjivosti tohoto

14 H. Buczyńska-Garewicz, Metafizyczne rozważania o czasie. Idea czasu w filozofii i literaturze, Kraków 2003, s. 183. 
světa je proti Máchově rozšířena o soucit, daný jeho vykupitelským heroismem, o naději, která variuje máchovskou věřícně popěratelskou metafyziku"15. Jednak pomimo chrześcijańskiej nadziei świadomość czasowości egzystencji ludzkiej przynosi duchową trwogę, która określa całe istnienie człowieka na ziemi ${ }^{16}$. Nie wynika ona co prawda w żaden sposób z nihilistycznie pojmowanej przyszłości, ale z faktu znajdowania się wobec przekraczającej granice rozumienia człowieka tajemnicy wieczności, absolutnej bezczasowości, do której można dostać się, jedynie przechodząc przez próg śmierci. Čepowski bohater żyje w „czasie”, choć stale w perspektywie wieczności, dzięki czemu oba wymiary przenikają się w jego świecie, o czym sam autor pisze:
Ale fyzický prostor, který nás obklopuje, také není prostorem uzavřeným; proniká jím všude a v každou chvíli jiná Př́tom- nost, která je nad každým prostorem a nad každým trváním. Pozorný pohled věcí, krajin a jejich obzorů je jenom odrazem jiného pohledu; toho pohledu, který všecko vidí a všecko shro- mažd'uje ${ }^{17}$.

Sfera realna w opowiadaniach Čepa byłaby zatem dla bohaterów tylko stopniem na drodze do całkowitego wymiaru niefizykalnego. Zauważył to również Jiří Svoboda, który pisze: „Čepovi hrdinové směřují k něčemu prapůvodnímu, jako by v hloubkách svých niter hledali obraz ráje, harmonický a št'astný svět. Odtud pocit vyhnanství, cizoty a stesku, s nímž jsou nuceni se vyrovnávat"18.

15 B. Fučík, Jan Čep, w: idem, Rodná krajina básníkova, Praha 2003, s. 307.

16 Trwoga (úzkost) jest u Čepa jednym z głównych elementów ludzkiego bycia na ziemi, określających jego sytuację duchową i egzystencjalną. Pojawia się nie tylko jako składnik duchowej konstrukcji bohaterów światów literackich kreowanych przez pisarza, ale też często w esejach oraz w tytule napisanego na emigracji eseju autobiograficznego, Sestra úzkost z 1965 roku.

17 J. Čep, Poutník na zemi..., op. cit., s. 227.

18 J. Svoboda, Člověk mezi dvěma krajinami (Polarita domova a cizosti v próze Jana Čepa), „Česká literatura” 1998, nr 6, s. 571. Przedruk tego tekstu z drobnymi zmianami również w: idem, Cesty a zastavení. Kapitoly z české literatury dvacátého století, Ostrava 2002, s. 76-83. 
Owo „poszukiwanie raju” znajdziemy oczywiście także u Máchy, choćby w Pouti krkonošskiej, gdzie znaczeniowo ,wsparte” dodatkowo obrazem pielgrzyma może nabierać głębszych sensów. Jakkolwiek jasna jest tu romantyczna proweniencja owego obrazu-symbolu, jego związek z romantycznym idealizmem i rozczarowaniem rzeczywistością, to nasuwa się pewna analogia do podobnego motywu u Čepa: życia rozumianego jako wędrówka i pielgrzymka do „drugiego domu”, tego po śmierci, w rzeczywistości Bożej. U katolika motyw ten opiera się co prawda na chrześcijańskiej nadziei, tak różnej od romantycznego (często nihilistycznego) rozczarowania, jednak ich podobieństwo tkwi w samej warstwie egzystencjalnej-u źródła owego obrazu, w miejscu, w którym ludzka egzystencja pojmowana jest w kategoriach tajemnicy i w którym materialny i metafizyczny wymiar istnienia dopełniają się. Proponowana przez Máchę za każdym razem subiektywna wizja człowieka i jego jednostkowego losu - człowieka stojącego pomiędzy dwiema przepaściami, czasem utraconym a nieznaną mu przyszłą nieskończonością, człowieka świadomego konfliktu pozorów i rzeczywistości i ostatecznie zawsze samotnego, pełnego egzystencjalnego niepokoju, który rodzi się z pragnienia poznania istoty świata oraz dotarcia do sfery absolutnej i idealnej - została przez Čepa odczytana jako bliska jemu samemu, wyrażająca jego artystyczny i życiowy światopogląd. Najpełniej Čep wyraził się w tej materii w artykule zatytułowanym Žizen̆ po věčnosti, który ukazał się w piśmie „Slovo a slovesnost” w 1936 roku jako jedna z wielu wypowiedzi czeskich pisarzy w ankiecie Básnický dně̌ek a K. H. Mácha:

Co nám dělá Máchu tak blízkým a srozumitelným, je palčivá naléhavost jeho poezie, jeho př́mé uchopení věcí, jeho ostré vedení rány na naše srdce. Jeho postoj k životu a k jeho tajemství, $\mathrm{k}$ záhadě lidské existence mezi propastí dvojí nekonečností, jeho touha po proniknutí k samé substanci bytí, po jistotě, ztělesňuje pro nás samu dřeň lidské zkušenosti na zemi. Jeho drásavá nostalgie, která tiskne k srdci zemi jako svou jedinou kořist, svou kolébku i hrob, ale přes ni už upírá žádostivý a vytřeštěný zrak kamsi k jiným břehům, k jiné a větší jistotě, je pro nás nepochybným svědectvím jeho duchovního rodu. (...) Jsme přesvědčeni, 
že tajemství jeho trvalé aktuálnosti je $\mathrm{v}$ tom, že vyjadřuje elementární žízeň, která pálí v každém lidském srdci ${ }^{19}$.

Tym, co wydaje się wspólne obu twórcom, jest więc próba rozpoznania podstawowej, ontologicznej sytuacji człowieka w świecie: jego sposobu bycia i relacji z rzeczywistością, przede wszystkim z czasem, miejscem, ale też z innymi ludźmi. W jakiejś mierze pojawia się tu zatem nawiązanie do egzystencjalizmu, dla którego - jak go diagnozuje w latach czterdziestych XX wieku Václav Černý - „východiskem je subjektivita individua, tj. osobní vědomí postihující sebe samo”. Egzystencjaliści „vidí jedinou př́mo poznatelnou skutečnost v holém procesu existování, jejž každý vnímá v sobě, tedy jednotlivě. Tato skutečnost je cizí jakékoliv definici rozumové, dedukci, systému: žijeme ji, nikoliv myslíme, je osobním a originálním, veskrze konkrétním sebeprožitkem" ${ }^{20}$. Oznacza to dalej, że świat ,jest nesčíslněkrát poznáván a interpretován, pokaždé jinak a pokaždé pravdivě"21, a więc zawsze dany jako konkretne, subiektywne przeżycie - choć jednocześnie jego obiektywne istnienie nie jest zanegowane. Odwołując się do nurtu filozofii egzystencjalistycznej, łatwo oczywiście wpaść w pułapkę jej wielokierunkowości i wieloznaczności. „Existencialismů je prý tolik, kolik je existencialistů"22 - pisze Černý; niemniej jednak istnieje pewna wspólna im wszystkim myślowa podstawa: świadome przeżywanie swojej własnej egzystencji, problem wolności i odpowiedzialności, relacje ze światem, które rodzą trwogę i niepokój wewnętrzny. Właśnie ta podstawa pozwala widzieć w filozofach i pisarzach nieegzystencjalistach ich prekursorstwo lub myślowy związek z tym nurtem. Čepa nazywano już egzystencjalistą katolickim ${ }^{23}$ (on sam przyznawał, że jego poglądy najbliższe są tym, które prezentował Jacques Maritain,

19 J. Čep, Rozptýlené paprsky..., op. cit., s. 131.

20 V. Černý, První a druhý sešit o existencialismu, Praha 1992, s. 26.

21 Ibidem, s. 32.

22 Ibidem, s. 25.

23 Czyni tak Jaroslav Med w kilku swoich artykułach: Křest'anský existencialismus v české kultuře (1945-1948), w: idem, Od skepse k naději. Studie a úvahy o české literatuře, Svitavy 2006, s. 103-105; Svět esejů Jana Čepa, „Dokořán” 1998, nr 6, s. 21-23; , ,Básník jitřního zraku”-Jan Čep, w: idem, Spisovatelé ve stínu, Praha 2004, s. $109-113$. 
francuski współczesny mu neotomista, personalista, chrześcijański humanista ${ }^{24}$ ) i rozważano jego prozę w szerokim kontekście literatury, która zajmuje się fenomenem ludzkiej egzystencji ${ }^{25}$. We wczesnych latach pięćdziesiątych, a więc już na emigracji, o egzystencjalizmie wypowiedział się też w jednym z esejów sam Čep:

Termín filozofie existencialistická stal se už dnes běžným, ačkoliv se jím kryjí duchovní tendence často velmi různé, ba protichůdné. Útočný ateismus Sartrův nemá mnoho společného s ušlechtilým stoicismem Camusovým, tím méně s křest’anskou nadějí Gabriela Marcela, nebožtíka Landberga (který zahynul v nacistickém vězení v Německu) nebo Maurice Nédoncella. Společným znakem existencialistického postoje k životu je typická úzkost moderního člověka, úzkost z budoucnosti, ze smrti, ba ze samého bytí, bolestně zaostřené vědomí existence bezbranného lidského osudu uprostřed nezvládnutelných iracionálních sil, které jej převyšují. Podle základního duchovního zaměření těch, kteří prožívají tuto lidskou zkušenost - a kteří ji vesměs vyjadřují smíšeným jazykem filozofickým a básnickým, spíše metaforou než pojmem - vyúst'uje toto vidění v zoufalou nesmyslnost, nebo v hluboce prožitou a konkrétně zaktualizovanou, nezaměnitelnou zkušenost víry ${ }^{26}$.

Ów wspólny rys różnych postaw egzystencjalistycznych, niezależny od wyboru opcji czy to religijnej, czy ateistycznej, akcentujący problem samego istnienia w świecie, okazuje się tym miejscem, w którym mogą spotkać się dziewiętnastowieczny romantyk i dwudziestowieczny katolicki prozaik. Występujące i będące zarówno u Čepa, jak i u Máchy główną „osią znaczeniotwórczą" w utworach motywy śmierci, wędrówki/pielgrzymki, ludzkiej samotności oraz czasowości wyrastają ze wspólnego obu twórcom, a jednocześnie ich bohaterom literackim, metafizycznego niepokoju. Ma on oczywiście różne korzenie w obu przypadkach i pro-

24 J. Čep, Tři pocestní, w: A. Kratochvil, ... za ostnatými dráty a minovými poli... Vzpomínky a svědectví, Mnichov - Brno 1993, s. 69-70.

25 V. Papoušek, Existencialisté. Existenciálni fenomeny v české próze dvacátého století, Praha 2004.

26 J. Čep, Samomluvy a rozhovory, Praha 1997, s. 65-66. 
wadzi do różnych rozwinięć tematycznych i strukturalnych w utworach, jednak, jak trafnie ocenia Bedřich Fučík, ,rozhodující je básnicky vyzpívané tragické drama života, jeho vnitřní napětí a ztvárnění' '27. Zawsze też, zarówno u Máchy, jak i u Čepa, niepokój wiąże się z kwestią ontologii ludzkiego bytu - jego pochodzenia, sposobu istnienia, jego, mówiąc językiem Heideggera, bycia-w-świecie. Pojawiające się zatem u obu twórców problemy ludzkiej samotności, czasowości, wędrówki/pielgrzymki czy śmierci, choć mogą być różnie rozwijane i interpretowane, odnoszą się za każdym razem do problemu egzystencjalnej sytuacji człowieka i wynikają z dominującego w nim poczucia niepokoju.

Ten metafizyczny niepokój, mający swe źródło w dostrzeganiu tajemnicy otaczającej istnienie człowieka $\mathrm{i}$ w nienasyconym pragnieniu wieczności, okazuje się też u obu autorów źródłem ich twórczości. „Není pochyby, že všechno umění vychází ze stejného zdroje, z obdobné reakce umělcova nitra na vnější svět, z obdobného úsilí po výraze"28 - pisze Čep, po czym wyjaśnia dalej: „Slovesné dílo, které vyjadřuje básníkovo vidění světa, je tedy především závislé na druhu a povaze básníkova nadání, na jeho sensibilitě a obraznosti, na jeho schopnosti výrazové"29. Ten moment szczerego aktu twórczej kreacji i właściwego ujarzmienia w słowie swojej wizji świata odnalazł Čep właśnie u autora poematu Máj:

Mácha našel na vrcholku své tvorby adekvátní výraz pro své vidění světa, pro svou sžírající žízeň, jeho inspirace se plně vtělila v tvar. Proto si zachovalo jeho dílo schopnost znovu a znovu otřásat dušemi nových čtenářských generací a rozorávat je ostřím své intenzity ${ }^{30}$.

Fascynacja pisarstwem Máchy odpowiada zatem także rozwijanej przez Čepa, zwłaszcza w przedemigracyjnych esejach, wizji poety i źródeł jego twórczości. Sztuce i artyście przyznaje on wyjątkową rolę $\mathrm{w}$ świecie, rolę, która wynika ze szczególnych predyspozycji duchowych twórcy i stawia go w miejscu niedostępnym innemu

\footnotetext{
27 B. Fučík, Jan Čep..., op. cit., s. 307.

28 J. Čep, Rozptýlené paprsky..., op. cit., s. 23-24.

29 Ibidem, s. 25.

30 Ibidem, s. 131-132.
} 
człowiekowi. Poeta, według Čepa, w sposób bardziej intensywny niż inni przeżywa rzeczywistość i dostrzega jej niematerialną stronę (bądź pragnie ją dostrzec, poszukując absolutu), która także tworzy jej istotę. Jego podstawowym doświadczeniem życiowym jest głębokie odczucie tajemnicy ogarniającej rzeczywistość i przenikającej ludzki los.
Básník - pisze Čep - je zrozen do tajemství, které ho naplňuje ustavičnou žízní a táhne proti proudu věcí a času k jejich skry- tému prameni. Odtud onen bolestný, ale zároveň slavný paradox jeho postavení, které by nevyměnil za žádnou výhodu hmotnou: jeho jakási dvojmístnost, vášnivé přilnutí k věcem pomíjejícím, k sladké látce tohoto času, a zároveň jeho ustavičná nenasyce- nost př́tomným okamžikem, jeho nostalgie po krajině ,,pahorků věčných”, po zdroji věčného světla, krásy, jednoty a lásky ${ }^{31}$.

Źródłem twórczości jest rodzący się ze świadomości tajemnicy, która ogarnia świat, metafizyczny niepokój, niezaspokojone duchowe pragnienie, którego nie może napełnić żadne ziemskie zdarzenie ani rzecz $^{32}$. Każde dzieło wyrasta więc ,z potřeby uniknout efemerní rozdrobenosti našeho času, z přiznaného nebo nepřiznaného vědomí nebo tušení, že žijeme zároveň v světě viditelném i neviditelném"33.

Máchę różni od Čepa wiele: uprawiany gatunek literacki, filozoficzna podbudowa tekstów, wyznawane idee i światopogląd, zarówno na płaszczyźnie twórczej, jak i w codziennym życiu. Jednak próby zrozumienia przez romantyka istoty ludzkiego bycia-w-świecie, wskazywanie egzystencjalnych problemów owego bycia, pozwala Čepowi na dostrzeżenie w dziele Máchy jakości nie tyle związanych z romantyczną aksjologią, ile tych uniwersalnych, najgłębiej dotykających problemu egzystencji ludzkiej. W takim ujęciu tym, co autora katolickiego fascynuje u czeskiego romantyka, jest po prostu olbrzymia siła poetyckiego języka oraz siła indywidualności jego bohaterów i płynąca z niej subiektywna wizja człowieka, jego jednostkowego losu i egzystencji.

\footnotetext{
31 Ibidem, s. 122.

32 Ibidem, s. 47.

33 Ibidem, s. 52.
} 
Być może właśnie swoje wrażenia z lektury poematu Máchy wplata pisarz w wykreowany przez siebie świat w tytułowym opowiadaniu zbioru Polní tráva (1946), który - co warto wspomnieć - wykazuje duże związki z egzystencjalizmem katolickim (Jaroslav Med twierdzi nawet, że proza Čepa jest jedyną w czeskiej literaturze powojennej odmianą tego nurtu na literackim polu ${ }^{34}$ ). Máj wzbudza tam w głównej postaci Tomaszu Suchomelu poczucie obcowania z tajemnicą i nieznaną mu rzeczywistością; rodzi niejasną świadomość przekraczania horyzontu codziennych zdarzeń:

V srdci mladého muže vyvstávalo cosi nejasného a dřímajícího, jako tušení neznámých světů, jako znění neznámých harmonií. Cítil s litostí svou němotu, němotu země i lidí, kteří jdou životem jako spící, se zavázanýma očima i ušima. Byl by chtěl znát víc, byl by se chtěl naučit jazyku, kterým se vyslovuje nevyslovitelné. Bylo mu líto, že nemohl chodit do škol jako ti mužové, jejichž verše ho omamovaly a o kterých se dočítal, že pocházeli právě z takových chaloupek jako on ${ }^{35}$.

W dobie licznych współczesnych Čepowi dyskusji dotyczących twórczości Máchy oraz romantyzmu w kulturze i literaturze czeskiej, a także sporów o faktyczny czy rzekomy katolicyzm romantycznego poety $^{36}$, Čep wydaje się pozostawiać na uboczu takie rozważania. Nie wskazuje też na żadną znaczącą linię rozwoju w czeskiej literaturze, która miałaby prowadzić od romantyzmu do twórczości katolickiej. Wzmianki o Másze świadczą o jednym: jego fascynacja dziełem romantyka jest fascynacją czytelnika i twórcy. Čep odnajduje u Máchy to, co dla niego samego w życiu i pracy twórczej wydaje się najważniejsze - bliską sobie wizję człowieka i świata, człowieka jako przeżywającą siebie egzystencję, a jednocześnie też wizję sztuki i jej źródeł.

34 J. Med, op. cit., s. 104.

35 J. Čep, Polní tráva, Brno 1946, s. 39.

36 M. C. Putna, Či je Mácha?, „Souvislosti” 1993, nr 4-5. 


\section{Literatura}

Buczyńska-Garewicz H., Metafizyczne rozważania o czasie. Idea czasu w filozofii i literaturze, Kraków 2003.

Čep J., Polní tráva, Brno 1946.

Čep J., Rozptýlené paprsky, Praha 1993.

Čep J., Samomluvy a rozhovory, Praha 1997.

Čep J., Poutník na zemi, Brno 1998.

Černý V., První a druhý sešit o existencialismu, Praha 1992.

Fučík B., Píseň o zemi, Praha 1994.

Fučík B., Rodná krajina básníkova, Praha 2003.

Haman A., Trvání v proměně. Česká literatura devatenáctého století, Praha 2007.

Kratochvil A., ... za ostnatými dráty a minovými poli... Vzpomínky a svědectví, Mnichov-Brno 1993.

Mácha K. H., Máj, Praha 1983.

Med J., Od skepse k naději. Studie a úvahy o české literatuře, Svitavy 2004.

Měšt’an A., Česká literatura mezi Němci a Slovany, Praha 2002.

Papoušek V., Existencialisté. Existenciální fenomeny v české próze dvacátého století, Praha 2004.

Putna M. C., Česká katolická literatura v kontextech 1918-1945, Praha 2010.

Putna M. C., Čí je Mácha?, „Souvislosti” 1993, nr 4-5.

Svoboda J., Člověk mezi dvěma krajinami (Polarita domova a cizosti v próze Jana Čepa), „Česká literatura” 1998, nr 6, s. 570-575.

Víra a výraz. Sborník z konference „,...bývalo u mne zotvíráno...”, red. T. Kubíček, J. Wiendl., Brno 2005. 